\title{
Pendampingan Re-Branding Produk Kopi Kelompok Tani Harapan Desa Amadanom
}

\author{
Havidz Ageng Prakoso ${ }^{1}$., Mochamad Aan Sugiharto ${ }^{2}$, Erfan Dani Septia ${ }^{3}$ \\ ${ }^{12}$ Fakultas Ilmu Sosial dan Ilmu Politik, Universitas Muhammadiyah Malang, Jalan Raya Tlogomas no 246 Kota \\ Malang \\ ${ }^{3}$ Fakultas Pertanian dan Peternakan, Universitas Muhammadiyah Malang, Jalan Raya Tlogomas no 246 Kota \\ Malang \\ E-mail Korespondensi: aansugiharto@umm.ac.id. 081210111187
}

Received: 1 Januari 2021; Revision: 10 Februari 2021; Accepted: 30 Maret 2021

\begin{abstract}
Abstrak
Desa Amadanom di Kecamatan Dampit cukup dikenal dengan produk kopinya, akan tetapi memiliki masalah dengan branding. Meski di desa Amadanom terdapat beberapa kelompok petani kopi dan beberapa merk kopi lokal, tetapi mereka mengalami kendala dalam hal membranding merk kopi yang telah ada agar bisa bersaing dengan produk-produk sejenis, baik di pasar nasional maupun global. Desain kemasan, logo dan taglineyang menarik menjadi penting untuk membentukbrandsuatu produk, yang mana ketiga hal tersebut belum dimiliki oleh kelompok tani kopi desa Amadanom, dalam hal ini adalah kelompok tani "tani harapan” yang sejak didirikan tahun 2001 belum memiliki brand yang bisa untuk bersaing dengan produk sejenis yang sudah ada.Untuk membantu mengatasi kendala-kendala yang dihadapi kelompok tani "tani harapan” dalam menciptakan brand kopi produksinya, akan dilakukan beberapa langkah; 1). Ceramah/diskusi: melakukan sosialisasi tentang pentingnya sebuah brand, hal tersebut bisa dilakukan mengingat anggota kelompok tani "tani harapan" rutin mengadakan pertemuan pada hari kamis minggu pertama setiap bulan. Di sini juga akan disosialisasikan pentingnya digital marketing serta media media yang efektif untuk melakukan media promosi produk. 2). Demonstrasi: memberikan pelatihan tentang membuat desain kemasan produk yang menarik, termasuk di dalamnya pemilihan logo, font tulisan dan tagline. Dalam hal ini, "kopi amadanom" disepakati menjadi brand kopi produksi kelompok tani "tani harapan". Selain itu, akun media sosialinstagram dan facebook"kopi amadanom" dibuat untuk media pemasaran dan pengenalan kepada masyarakat luas. 3). Pendampingan: mendampingi kelompok tani "tani harapan" secara intensif dan berkelanjutan terutama dalam penguatan rebranding produk kopi "kopi amadanom”.
\end{abstract}

Kata Kunci : Kopi, Re-Branding, Kelompok Tani, Tani Harapan, Amadanom Sugiharto, A., \& Ageng Prakoso, H. (2021). Pendampingan Re-Branding Produk Kopi Kelompok Tani Harapan Desa Amadanom. Masyarakat Berdaya Dan Inovasi, 2(1). Doi:Https://Doi.Org/10.33292/Mayadani.V2i1.50

This is an open access article under the $\underline{\mathrm{CC}-\mathrm{BY}-\mathrm{SA}}$ license.

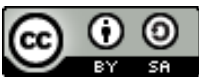

\section{PENDAHULUAN}

Persoalan penting yang dihadapi oleh petani kopi di Indonesia adalah harga jual dan branding, padahal Indonesia menjadi penghasil kopi arabika terbaik di dunia dan sebagai penghasil kopi robusta terbaik kedua di dunia setelah Vietnam. Harga jual yang fluktuatif dan variatif di tingkat petani kopi, membuat petani kopi belum merasakan keuntungan yang optimal dari sistem perdagangan kopi (akhmad zakaria dkk, 2017). Karena itu, sejak pertama kali diperkenalkan pada pertengahan abad ke-17 oleh Belanda, potensi sumber daya agribisnis kopi Indonesia belum dimanfaatkan secara optimal. Hal tersebut diketahui dari tingkat produktivitas kopi Indonesia baru mencapai 760 kg/hektar (H. Rahmat Rukmana, 2014).Di Indonesia, perkebunan kopi tersebar di pulau-pulau besar seperti Sumatera, Jawa, Bali, Nusa 
Tenggara, Sulawesi, Maluku dan Papua yang sebagian besar perkebunan itu milik petani (perkebunan rakyat).

Sejalan dengan prioritas program pemerintah nasional dalam pengembangan komoditas perkebunan sejak periode tahun 2010 - 2014 hingga 2015 - 2019, yang dimana kopi menjadi salah satu komoditas spesifik dan potensial dari 15 komoditas yang ada diwilayah masing - masing (Dr. Yusman Syaukat, 2015). Berdasarkan hasil Identifikasi Isu-Isu Strategis sebagaimana yang dirilis melalui Renstra Pemerintah Provinsi Jawa Timur dalam dinamika Internasional yaitu dengan laju pertumbuhan penduduk dunia yang semakin meningkat hal ini linear dengan semakin besarnya kebutuhan manusia sehingga mengakibatkan alih fungsi lahan, khususnya pertanian yang seharusnya dapat menjadi lumbung ketahanan pangan ke non pertanian, sehingga memiliki dampak pada terbatasnya ketersediaan pangan dunia, serta dalam dinamika Nasional; semakin ketat daya saing komoditas ekspor, akibat konsekuensi perdagangan liberal dengan makin terbukanya perdagangan internasional. (Pemprov Jawa Timur, 2014)

Desa Amadanom kecamatan Dampit Kabupaten Malang Jawa Timur sudah cukup dikenal sebagai daerah penghasil kopi. Setidaknya terdapat 4 (empat) kelompok tani kopi di desa Amadanom, yang hampir dari setiap kelompok tani tersebut memiliki merk kopi mereka sendiri seperti merk kopi burung beo, namun produk ini tidak memiliki karakteristik dari asal daerah dimana kopi ini diproduksi. Namun selama ini permasalahan yang dihadapi para pelaku prrodusen merk kopi produksi mereka belum mampu menembus dan bersaing dipasar yang lebih luas salah satu kendalanya adalah permasalahan branding dan promosi yang masih sangat konvensional.

Saat ini dalam memproduksi sebuah barang maka seller melakukan konsultasi dan melakukan research produknya terlebih dahulu serta prospek pasar, bahkan pasar produk kopi saat ini semakin meluas, dikarenakan jumlah penikmat kopi yang semakin meningkat dalam rangka mencari cita rasa kopi-kopi Indonesia yang variatif hal ini dibuktikan dengan konsumsi kopi yang meningkat hingga 1,3 - 1,5 per kapita/tahun sebagaimana yang disampaikan oleh Eris Susandi (Pengamat kopi dari Asosiasi Eksportir dan Industri Kopi Indonesia /AEKI). (Indira Rezkisari, 2017) Data yang didukung juga oleh International Coffee Organization (ICO) menunjukkan kurang lebih 155.491 (tahun 2015/16) 158.642 (tahun 2016/17) 162.555 (tahun 2017/18) 165.345 (tahun 2018/19) dengan satuan ribuan per 60kg/bags dalam konsumsi dunia. (ico.org, 2019).

Kemasan menjadi permasalahan yang cukup vital, karena konsumen pertama kali akan melihat dan menilai terlebih dahulu kemasan, karena kemasan juga butuh karakter yang akan dimunculkan dan mampu menarik konsumen dan meyakinkan. Saat ini konsumen pun menilai kemasan sehingga istilah don't judge it's by cover mulai tidak berlaku.

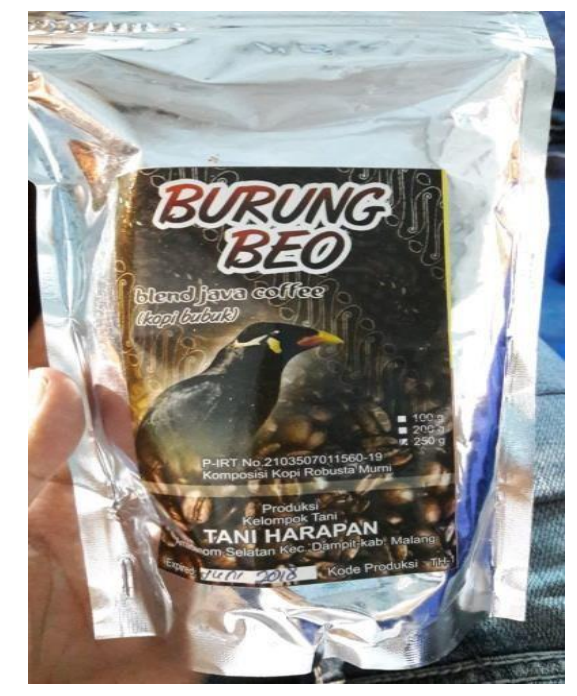

Gambar 1. Foto Produk sebelum re-branding

Sama seperti kelompok tani lainnya di desa Amadanom, kelompok tani "tani harapan" juga mengalami permasalahan serupa. Sejak didirikan pada tahun 2001 hingga saat ini (18 tahun), sebenarnya tani harapan selalu berupaya untuk menjadikan produk kopi masyarakat amadanom dikenal secara luas, 
tidak hanya di kecamatan Dampit. Tetapi karena berbagai keterbatasan, termasuk sumber daya manusia yang kurang memiliki keterampilan dalam membranding produk maupun financial untuk mendukung usaha tersebut. Kendala-kendala demikian terjadi karena selama ini kelompok tani harapan belum pernah mendapatkan pelatihan dan pendampingan yang secara spesifik menitikberatkan pada pentingnya re-branding produk kopi yang selama ini mereka hasilkan. Merk yang mereka miliki sebelumnya adalah merk yang tidak memiliki karakter dan mencerminkan produk khas Dampit kususnya Amadanom.

Hasil diskusi dengan pihak kelompok tani harapan, diketahui kendala terkait re-branding produk kopi kelompok tani harapan yang perlu diatasi pertama kali adalah tentang memberikan pemetaan tentang produk dan kekuatan berdasarkan lokasi produksi agar produk memiliki karakter yang cukup kuat dalam merepresentasikan asal produk melalui produk yang dihasilkan melalui kemasan, di mana nanti kemasan tersebut bisa digunakan oleh kelompok tani harapan untuk lebih mengembangkan dan mengenalkan produknya kepada masyarakat luas. Selain membuat logo-logo produk yang akan dihasilkan, akan ditreatment juga melalui penggunaan optimalisasi media online yang sedang trend dalam mengiklankan produk, yaitu instagram dan facebook, serta marketplace bukalapak.com.

\section{METODE}

Program pengabdian kepada masyarakat yang akan dilaksanakan ini menggunakan metode sosialisasi, pelatihan dan pendampingan kepada kelompok tani harapan dalam re-branding produk kopi mereka. Pembuatan desain kemasan termasuk di dalamnya adalah desain tulisan, font, warna, logo dan tagline merupakan aspek penting dari re-branding kopi Amadanom, sehingga dalam pengabdian ini, akan dilakukan sosialisasi, pelatihan dan pendampingan selama proses re-branding tersebut. Selanjutnya, pelatihan pemasaran juga perlu dilakukan terlebih di era digital saat ini yang mana pengenalan dan pemasaran produk bisa dilakukan dengan cara yang lebih variatif dan juga efisien.

Dengan memanfaatkan media sosial, proses pengenalan dan pemasaran suatu produk bisa lebih mudah, murah dan efisien. Dalam hal ini, media sosial Instagram dan facebook dipilih sebagai media untuk promosi dan pemasaran produk kopi amadanom. Selain membuat akun media sosial sendiri, nantinya juga akan menggunakan jasa endorse ke pemilik akun media sosial Instagram dan facebook yang mempunyai banyak follower. Hal itu seperti yang sudah banyak dilakukan oleh pelaku usaha lain agar proses promosi dan pemasarannya lebih efektif, contohnya adalah "Malang Strudle" yang menggunakan public figure Tengku Wisnu sebagai endorse produknya.

Masih memanfaatkan perkembangan teknologi, strategi pemasaran juga akan dilakukan dengan cara mendaftarkan Kopi Amadanom ke situs jual beli online Bukalapak. Hal ini adalah salah satu strategi pemasaran di era revolusi industry 4.0 di mana proses jual beli tidak perlu lagi terjadi pertemuan tatap muka antara penjual dan pembeli dan jangkauan pemasaran akan lebih luas karena bukalapak.com merupakan salah satu situs jual beli online besar dan popular di Indonesia.

Dalam proses sosialisasi, pelatihan dan pendampingan kepada kelompok tani harapan tersebut perlu dilakukan beberapa hal sebagai berikut:

1. Persiapan dan pembekalan

Adapun mekanisme pelaksanaan Pengabdian Bersaing yang akan dilaksanakan di kelompok tani harapan desa Amadanom Kecamatan Dampit adalah dengan melakukan persiapan dan pembekalan kepada 2 (dua) elemen, yaitu anggota kelompok tani harapan dan mahasiswa yang dilibatkan dalam program pengabdian bersaing ini. Tahapan- tahapannya adalah sebagai berikut:

a. Berkoordinasi dengan pihak mitra yaitu kelompok tani harapan desa Amadanom

b. Memberikan pembekalan kepada mahasiswa yang dilibatkan dalam pengabdian ini terkait dengan apa saja yang harus dilakukan dalam pendampingan re-branding produk kopi kelompok tani harapan desa Amadanom guna tercapainya tujuan dari program

c. Menyusun proposal pengabdian bersaing tahun anggaran 2019

Pada poin B, materi persiapan dan pembekalan yang akan diberikan kepada mahasiswa yang dilibatkan dalam program pengabdian ini adalah sebagai berikut:

a. Teknik pendekatan kepada masyarakat

b. Motivasi dan pengembangan kepribadian

c. Struktur kelembagaan sosial masyarakat desa

d. Tipologi masyarakat di pedesaan 


\section{e. Pentingnya penguatan kelembagaan kelompok tani}

2. Pelaksanaan

Pelaksanaan program pengabdian bersaing dengan judul "pendampingan re- branding produk kopi kelompok tani harapan Desa Amadanom" ini akan menerapkan beberapa langkah untuk keefektifan pencapaian tujuan program yang bisaditampilkan dalam tabel sebagai berikut:

Tabel 1. Langkah taktik program pendampingan

\begin{tabular}{|c|c|}
\hline Tahapan Program & Langkah Taktis \\
\hline $\begin{array}{l}\text { Mengidentifikasi } \\
\text { permasalahan } \\
\text { mitra }\end{array}$ & $\begin{array}{l}\text { a) Dengan ikut bergabung dalam rapat-rapat yang di } \\
\text { selenggarakan oleh kelompok Tani } \\
\text { b) Harapan kami mengamati permasalahan yang selalu muncul } \\
\text { dari pelaku usaha juga petani kopi yang ada di Amadanom } \\
\text { secara umum, } \\
\text { c) kelompok juga selalu mencoba untuk mencari nama produk } \\
\text { yang telah mereka hasilkan, serta kemasan yang menurut kami } \\
\text { juga kurang menarik untuk dipasarkan di pasar online. }\end{array}$ \\
\hline $\begin{array}{l}\text { Sosialisasi program kerja kepada } \\
\text { mitra }\end{array}$ & $\begin{array}{l}\text { a) Pada saat kesempatan berkumpul dengan perangkat dan anggota } \\
\text { kelompok Tani Harapan, ini sebagai waktu yang tepat dalam } \\
\text { mengutarakan program kami dalam membantu salah satu } \\
\text { kelompok tani yang ada di desa Amadanom ini. } \\
\text { b) Mendiskusikan tentang logo dan nama yang akan dijadikan } \\
\text { sebagai produk unggulan dari kelompok Tani Harapan, } \\
\text { c) Memberikan fasilitas pelatihan pembuatan logo dengan metode } \\
\text { riset produk brand identity kopi Amadanom /Brand Name } \\
\text { Research } \\
\text { d) Memberikan kesempatan produsen untuk menjajaki pasar digital } \\
\text { yang sangat kompleks, dengan metode brand image di media } \\
\text { social instagram. }\end{array}$ \\
\hline & $\begin{array}{l}\text { Pelaksanaan program kerja, melalui: } \\
\text { pendidikan/pelatihan/demonstrasi/pendampingan yang meliputi: } \\
\text { a) penguatan kelembagaan kelompok, } \\
\text { b) melakukan pendekatan kepada masyarakat khususnya para } \\
\text { anggota kelompok tani harapan untuk lebih mau berkomitmen } \\
\text { atas kemajuan kelompok tani harapan, } \\
\text { c) mendesain ulang brand dan logo kopi Amadanom, membuat } \\
\text { akun media sosial kopi amadanom, } \\
\text { d) langkah berikutnya }\end{array}$ \\
\hline $\begin{array}{l}\text { Diskusi berkala antara Fasilitator dan } \\
\text { Mitra }\end{array}$ & $\begin{array}{l}\text { a) dengan waktu fasilitas } 2 \text { bulan cukup untuk memberikan peserta } \\
\text { kemampuan dalam mengembangkan produk melalui } \\
\text { pembelajaran desain yang telah diberikan, dalam hal ini peserta } \\
\text { diberikan kesempatan untuk meminta mengulang materi melalui } \\
\text { media daring dari fasilitator dan pemateri yang fasilitator } \\
\text { sediakan, sehingga terjadi interaksi antara fasilitator dan mitra. } \\
\text { b) hal ini mampu meningkatkan kemampuan peserta pelatihan } \\
\text { meskipun tidak maksimal dalam pelaksanaan ini, butuhnya } \\
\text { kesadaran dari peserta dalam mendalami dan mendesain yang } \\
\text { baik berdasarkan metode desain kemasan yang proporsional dan } \\
\text { mampu menjadi representasi produk itu sendiri bahkan tempat } \\
\text { dari produk kopi ini berasal. }\end{array}$ \\
\hline $\begin{array}{l}\text { Evaluasi berkala (bulanan) terhadap } \\
\text { hasil kegiatan } \\
\text { yang telah dilaksanakan }\end{array}$ & $\begin{array}{l}\text { setiap kegiatan yang telah terlaksana memberikan ruang komentar dari } \\
\text { peserta ke fasilitator agar program menjadi maksimal, pada }\end{array}$ \\
\hline $\begin{array}{l}\text { Tindak lanjut dari hasil evaluasi } \\
\text { untuk menjamin } \\
\text { program berjalan sesuai dengan }\end{array}$ & \\
\hline
\end{tabular}


rencana

\section{HASIL DAN PEMBAHASAN}

Pada bulan April 2019, telah dilakukan kegiatan pertama dari pengabdian Pendampingan ReBranding Produk Kopi Kelompok Tani Harapan Desa Amadanom, yaitu mendatangi pihak mitra yaitu Kelompok Tani Harapan dan berkoordinasi terkait waktu dan lokasi pelaksanaan pelatihan dan pengelolaan website kopi amadanom. Pada tahap ini, tim bertemu dengan perwakilan Kelompok Tani Harapan di kantor Kelompok Tani Harapan.

Pada pertemuan ini, tim dan perwakilan kelompok Tani harapan menentukan siapa saja yang akan dilibatkan dalam sosialisasi dan pelatihan pengelolaan website kopi amadanom guna meningkatkan marketing dari produk kopi amadanom. Karena kesibukan masing-masing, baik dari kelompok Tani Harapan maupun tim pengabdian, maka baru disepakati pelatihan pengelolaan website kopi amadanom baru dilaksanakan pada Agustus 2019. Penentuan waktu pelaksanaan sosialisasi atas pertimbangan bahwa pada bulan agustus 2019 pihak Kelompok Tani Harapan baru bisa mempunyai waktu luang yang cukup dan bisa mengajak serta anggota-anggota yang muda setelah adanya pemilihan kepengurusan Kelompok Tani Harapan yang baru pada bulan Juli 2019. Pihak Kelompok Tani Harapan dan tim pengabdian merasa pelaksanaan pelatihan website akan optimal jika dilakukan setelah pergantian kepengurusan karena akan bisa berkesinambungan karena kepengurusan yang masih baru dan memiliki masa kerja panjang.

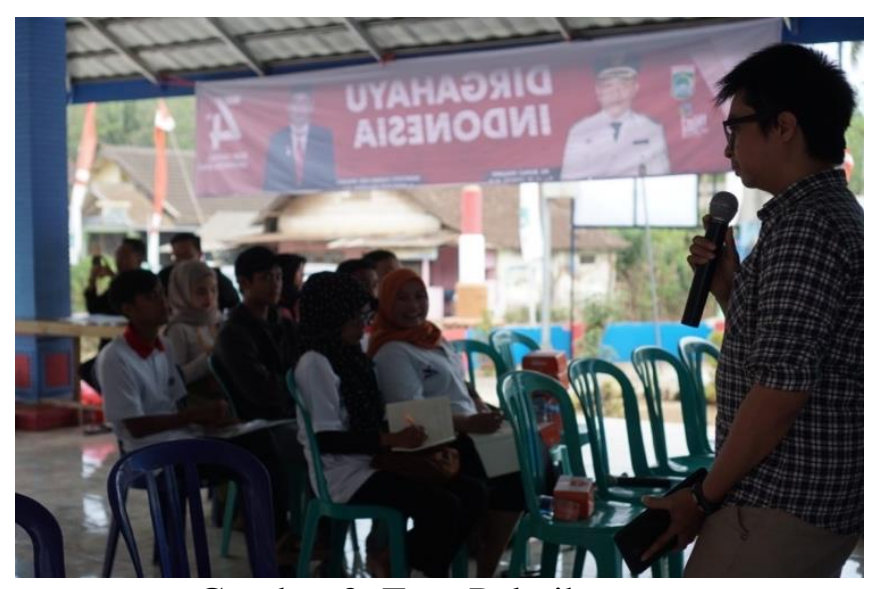

Gambar 2. Foto Pelatihan

Pelaksanaan pelatihan pengelolaan membuat design yang marketable tidak semudah membuat logo produk biasa, sehingga dilaksanakan pada hari kamis 1 agustus 2019 berlokasi di kantor Kelompok Tani Harapan yang dihadiri oleh pengurus Kelompok Tani Harapan. Dari pihak Kelompok Tani Harapan dihadiri oleh pengurus pusat dan beberapa tim marketing yang mayoritas adalah anak muda yang familiar dengan teknologi khususnya internet. Dari pihak tim pengabdian datang lengkap beserta mahasiswa yang dilibatkan dalam pengabdian ini.

Pada pelatihan ini juga ditentukan waktu pelaksanaan pelatihan pembuatan desain, logo dan tagline yang akan digunakan pada produk kopi amadanom. Hal ini sangat penting karena di era serba digital saat ini, tampilan luar sangatlah menentukan dari kesuksesan sebuah produk di pasaran. Hingga akhirnya pada bagian akhir pelatihan, didiskusikan dan disepakati bahwa pelatihan berikutnya dilaksanakan pada 13 agustus 2019 yang berlokasi di Kantor Desa Amadanom.

Setelah pelatihan yang dilakukan pada tanggal 13 Agustus 2019 bertempat di Kantor Desa Amadanom Kecamatan Dampit Kabupaten Malang, yang diikuti oleh seluruh anggota Kelompok Tani Harapan, maka kegiatan selanjutnya adalah pendampingan pembuatan logo baru dari produk yang telah di-rebranding. Dari kegiatan pendampingan pembuatan logo baru, yang diikuti oleh semua anggota Kelompok Tani Harapan, disepakati nama produk kopi dan logonya adalah Kopi Anom.

Nama Kopi Anom diambil dengan pertimbangan bahwa nama tersebut masih identik dengan Desa Amadanom, yaitu mengambil bagian belakang dari Desa Amadanom yaitu Anom. Harapannya, dengan 
menggunakan nama Kopi Anom, orang akan langsung mengetahui jika kopi tersebut adalah produk dari petani kopi di Desa Amadanom. Selain itu, nama Kopi Anom juga belum pernah digunakan oleh pihak manapun sehingga sangat tepat jika nama Kopi Anom dipilih sebagai rebranding produk kopi Kelompok Tani Harapan Desa Amadanom Kecamatan Dampit Kabupaten Malang.

Dibandingkan dengan nama produk sebelumnya, yaitu Burung Beo, maka nama Kopi Anom jauh lebih representatif karena diambil dari nama Desa Amadanom. Jika sebelumnya nama Burung Beo tidak mewakili keseluruhan produk dari Kelompok Tani Harapan, maka Kopi Anom merupakan produk yang mewakili dari keseluruhan produk kopi Kelompok Tani Harapan Desa Amadanom karena merupakan hasil kesepakatan seluruh anggota Kelompok Tani Harapan.

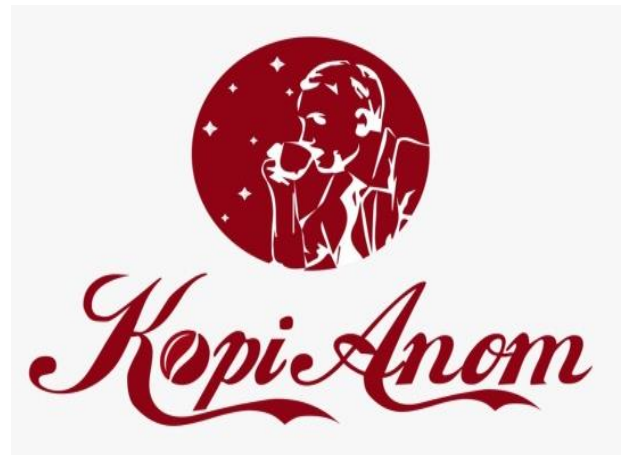

Gambar 3. Foto Produk

Setelah disepakati bahwa nama hasil rebranding adalah Kopi Anom, maka selanjutnya adalah pelatihan membuat logo yang berlangsung selama 1 (satu) minggu sejak tanggal 13 Agustus sampai tanggal 20 Agustus 2019. Pelatihan pembuatan logo dilakukan dengan menggunakan metode observasi produk dan locus dari produk berasal, sehingga mampu menciptakan representasi dari desa yang akan diangkat dan mampu menjadikan desa Amadanom juga sebagai branding dari segala produk-produk turunan dari kopi yang berasal dari desa Amadanom. Metode tersebut dipilih karena dengan menggunakan metode observasi produk dan locus produk, maka akan lebih mudah bisa menentukan akan seperti apa logo yang sesuai dan relevan dengan produk Kopi Anom yang telah di-rebranding.

Identifikasi pembuatan logo produk dengan kriteria; 1. Pemilihan kata Kopi Anom sebagai representasi objek pasar yang dituju serta fontnya mewakili wilayah amadanom yang berbukit-bukit sebagai penghasil kopi, 2. Pemilihan logo merah menandakan.

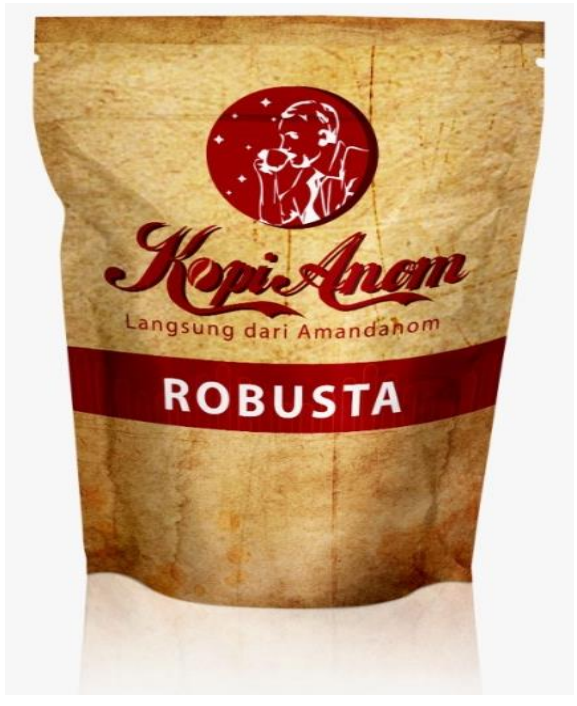




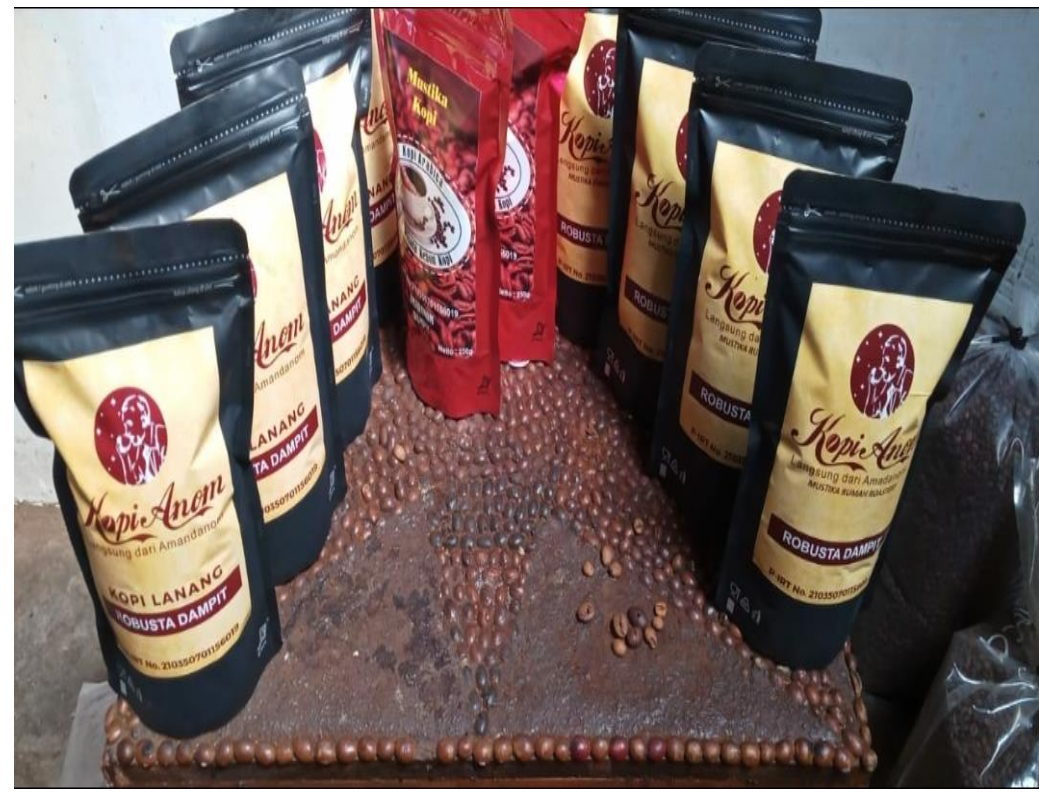

Gambar 4. Foto Dummy Produk

Setelah pendampingan selama 2 minggu, akhirnya disepakati dan tercipta logo, tagline, warna dan kemasan Kopi Anom. Tagline "langsung dari amadanom" semakin menegaskan bahwa Kopi Anom merupakan kopi hasil dari para petani di Kelompok Tani Harapan Desa Amadanom. Hal tersebut dilakukan dengan pertimbangan bahwa tidak semua orang yang berada di luar Malang mengetahui nama desa Amadanom, hal tersebut karena selama ini yang lebih dikenal oleh publik adalah Dampit sebagai daerah penghasil kopi di Kabupaten Malang.

Kegiatan selanjutnya adalah melakukan pendampingan pembuatan akun media sosial sebagai salah satu media untuk pemasaran dan promosi Kopi Anom. Media sosial saat ini hampir mendominasi kehidupan setiap orang, tak terkecuali dalam dunia pemasaran. Maka selain melakukan promosi dan pemasaran secara konvensional, pemasaran melalui media sosial juga sangat diperlukan di era revolusi industri 4.0.

Setelah akun media sosial terbentuk dan pengelola dan tim marketing sudah mahir menggunakan media sosial sebagai media pemasaran dan promosi, maka yang perlu dilakukan selanjutnya adalah memaksimalkan pemasaran melalui online. Tidak bisa dipungkiri, sejak tahun 2010 dengan semakin berkembangnya teknologi komunikasi dan informasi terutama online, banyak aktivitas jual beli dilakukan dengan menggunakan fasilitas online. Dalam program rebranding ini, Bukalapak dipilih sebagai partner dalam mempromosikan dan media pemasaran produk Kopi Anom. Alasan pemilihan bukalapak karena saat ini di Indonesia bukalapak merupakan media online/situs jual beli online yang paling banyak digunakan oleh pedagang di Indonesia. 


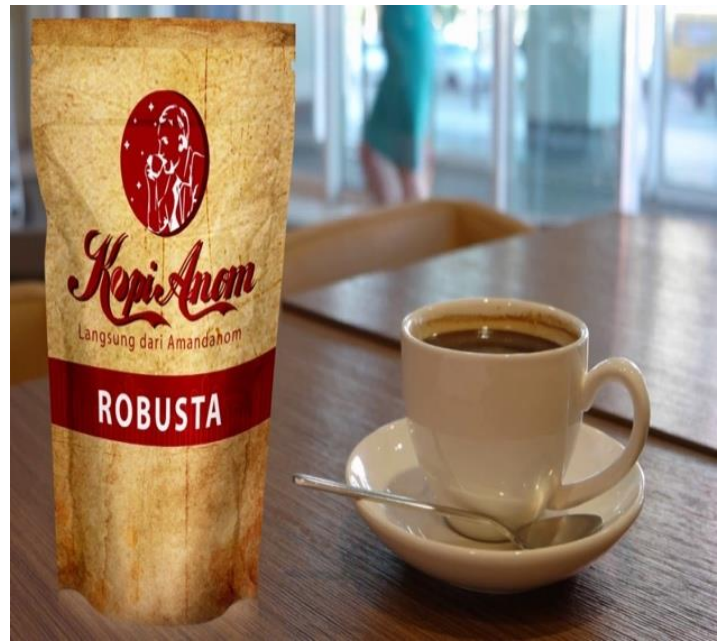

Gambar 5. Foto Produk Jadi Siap dipasarkan

Gambar di atas merupakan gambar yang digunakan di situs instagram karena menarik dan sangat representatif bagi kaum milenial pecinta kopi. Segmentasi penawaran via social media yang menjadikan solusi dalam mengatasi tersendatnya pasar konvensional.

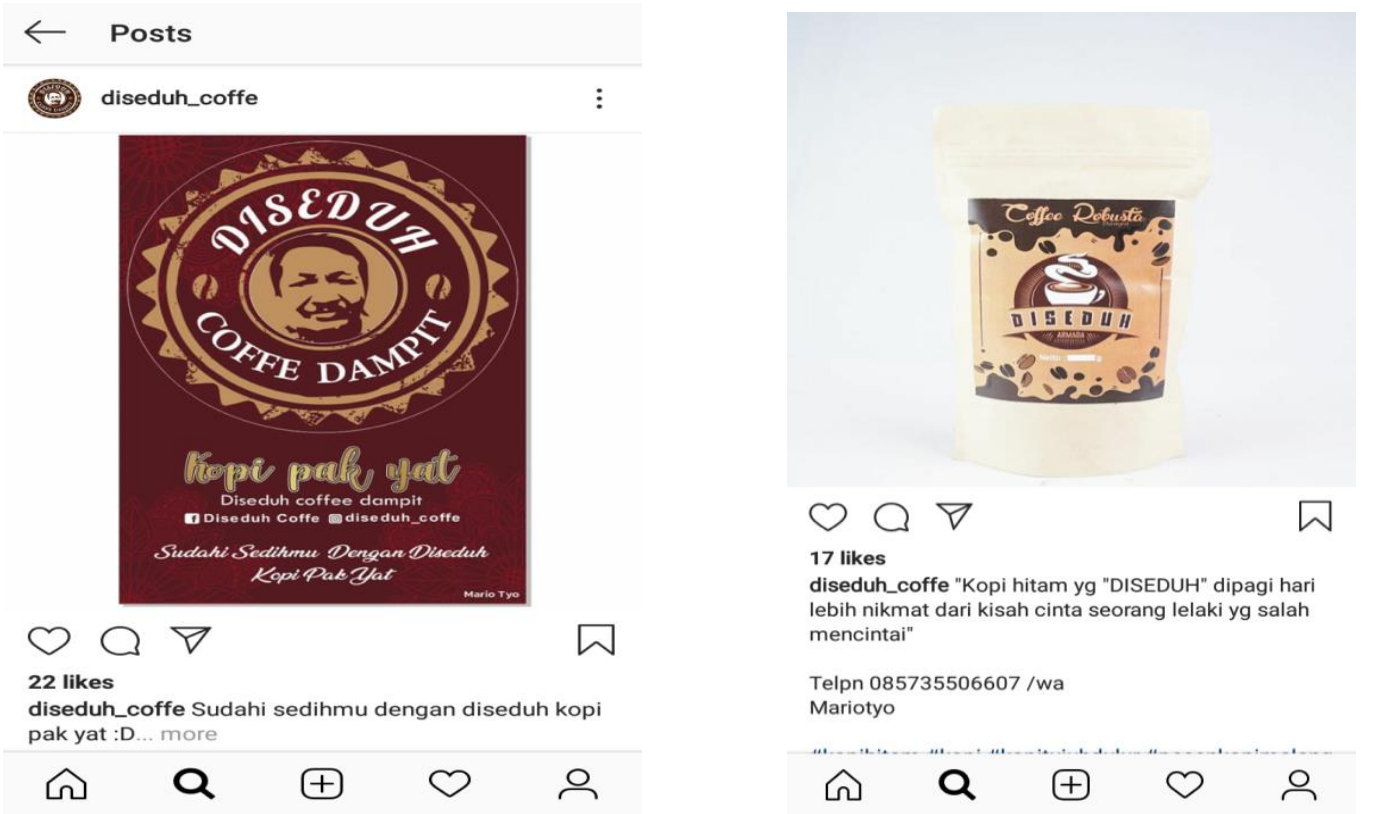




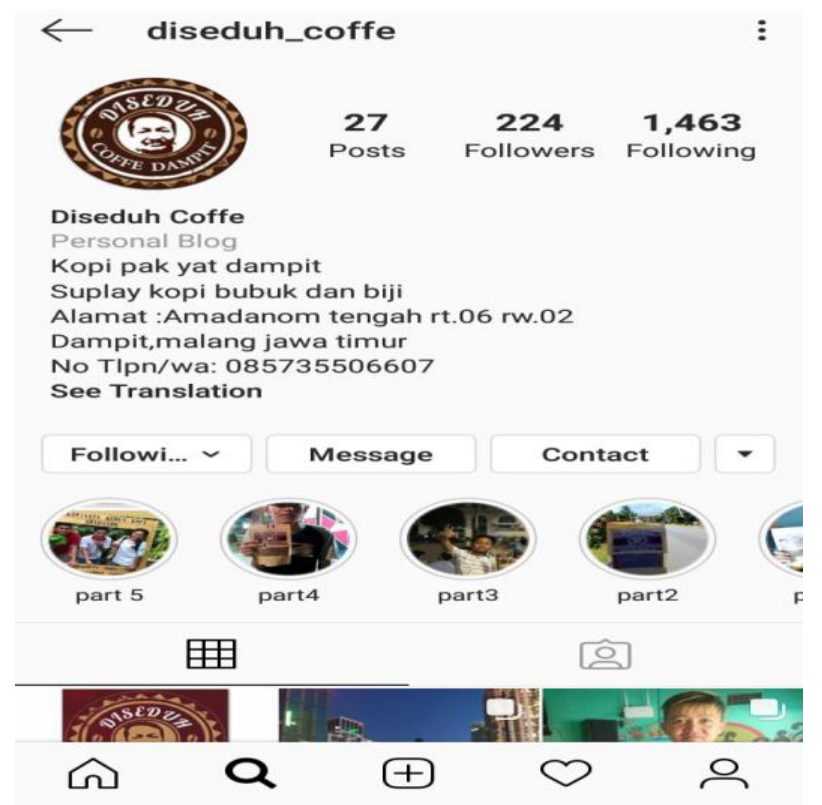

Memberikan pendampingan kepada petani muda dalam membranding produk-produk yang dihasilkan cukup membuat semangat karena era digitalisasi yang semakin mempermudah mengenalkan produk-produk utama seperti kopi yang akan merika kelola sendiri sebagai industri hulu hingga hilir, dimana dahulu pengolahan kopi hanya sampai pada penjemuran kopi hingga kering kemudian dijual secara besar-besaran ke penjual atau tengkulak yang notabene penjualannya tidak membuat petani senior puas akan hasil pendapatannya. Oleh karena itu semakin terbukanya petani-petani muda yang akan melanjutkan bisnis kopi ini dan mencoba mengambil segmentasi yang saat ini memiliki peluang besar dalam mengembangkan kopinya hingga sampai langsung ke tangan konsumen.

Salah satu platform yang paling banyak penggunanya yaitu instagram, instagram memiliki 319 juta pengguna aktif yang tercatat di akun resmi instagram, sehingga menjadikan salah satu peluang terbesar mempromosikan kopi Dampit khususnya Amadanom keberbagai belahan dunia, tidak hanya skala nasional tetapi skala yang lebih besar, dan tidak menutup kemungkinan menjual produk hingga luar negeri, dan mampu bersaing dengan kopi dunia lainnya. Bagaimana dengan solusi yang diberikan oleh kelompok pendamping mampu mengatasi batas-batas permasalahan yang dihadapi sebelumnya, selain transfer ilmu tentang pelatihan membuat kemasan dan logo yang lebih kreatif, imaginatif dan inovatif mampu membuat petani muda dan desa berdikari dan mulai melepaskan ketergantungan dengan pembeli biji kopi yang cenderung memainkan harga, ketika petani mampu mengolah sendiri maka akan memiliki pendapatan yang jaih lebih baik dan akan tetap mempertahankan tanaman kopi yang menjadi khas wilayah Dampit, dan petani muda mau melanjutkansebagai petani kopi yang mampu memberikan penghidupan yang jauh lebih layak. 


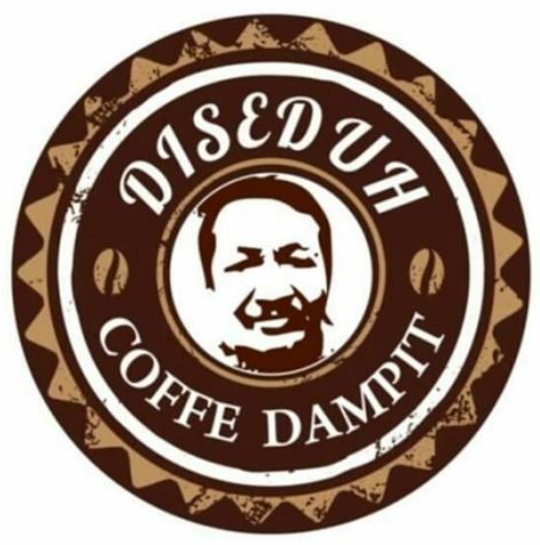

Diseduh Coffe memperbarui foto profilnya.

10 Agt pukul $14.24 \cdot 8$

kopi bubuk dampit $\odot \cdot$
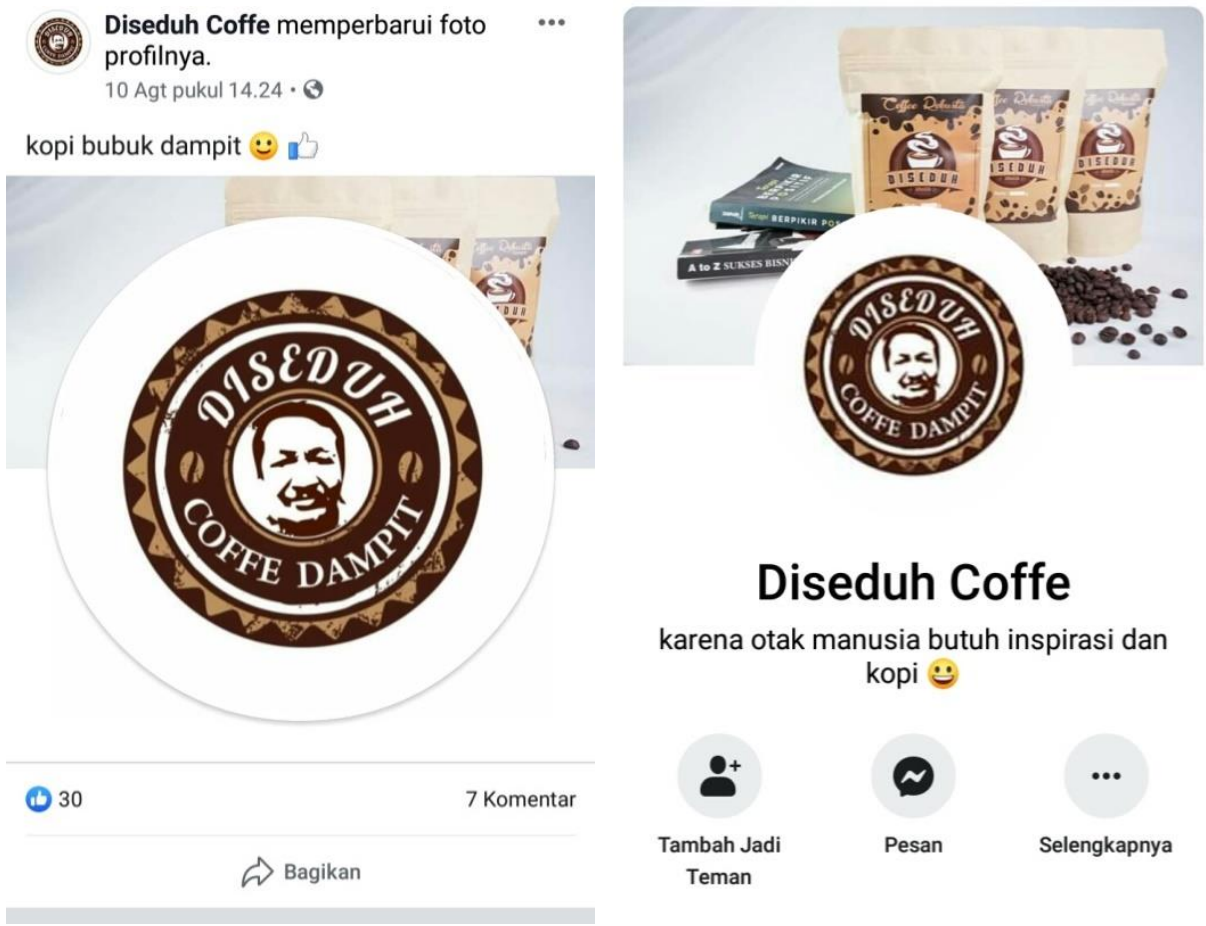

\section{Diseduh Coffe}

karena otak manusia butuh inspirasi dan kopi :-

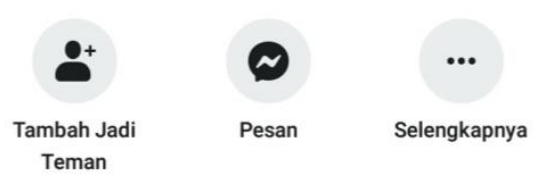



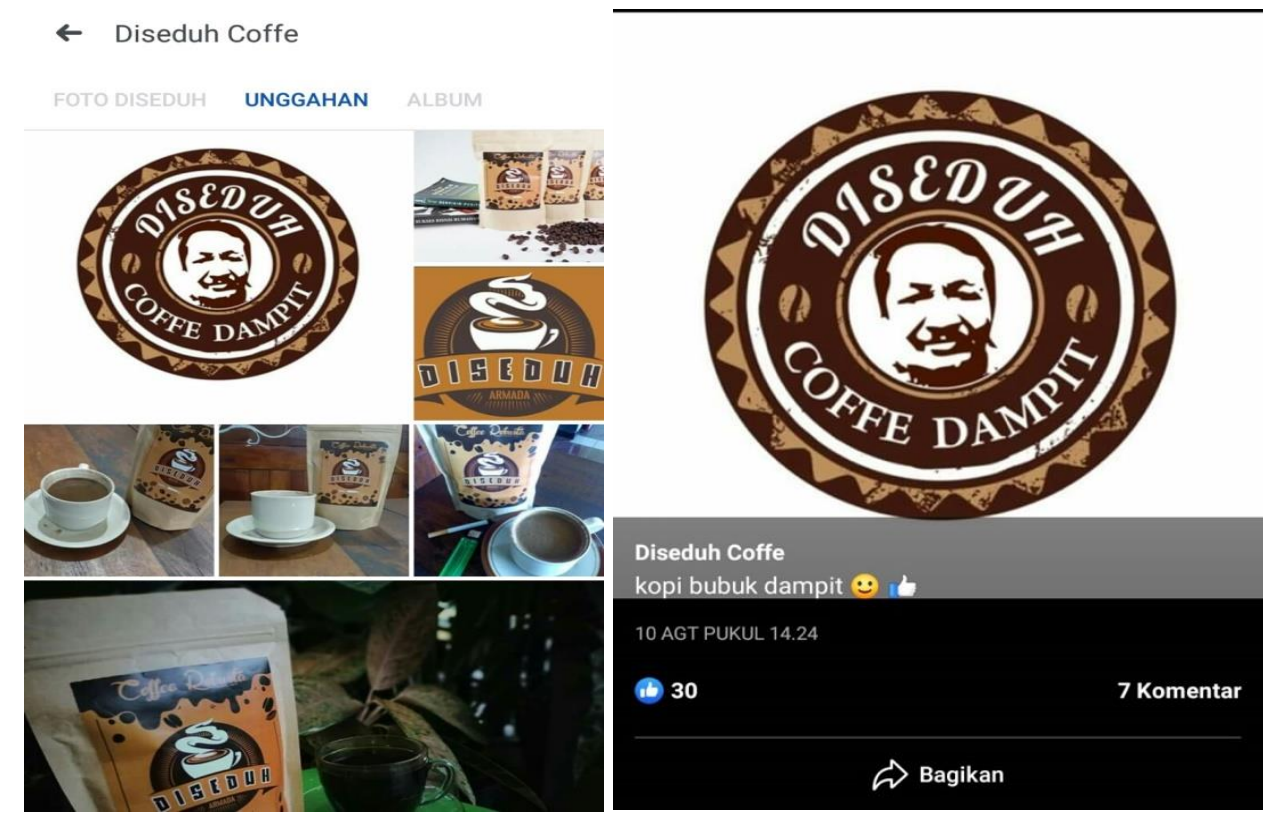

design yang sudah didaftarkan dan di publikasikan sebagai brand baru dari petani kopi lainnya adalah diseduh kopi Dampit, memberikan ke khasan pemiliknya dan mempopulerkan kopi robusta yang menjadi andalan desa, logo yang diintisarikan menjadi sebuah mediasi interaksi penikmat kopi dan penjual yang menunjukkan orang asli Amadanom. Design diseduh kopi Dampit ini selain melesat di instagram, juga dipromosikan menggunakan Facebook, kenapa facebook. Berdasarkan hasil pemetaan 25 peserta yang mengikuti pelatihan dan 2 yang sudah mampu menghasilkan produknya sendiri dan ingin mempromosikannya melalui facebook, dimulai dari rekan-rekan petani yang sudah menggunakan facebook dan mengenal facebook sejak 2010an dengan hanya menggunakannya sebagai sarana komunikasi harian saja. Dengan pendampingan penggunaan facebook secara optimal, mulai digunakan facebook dengan melakukan fasilitasi sesi foto-foto produk yang cukup rumit, akhirnya promosi yang layak dapat dipublikasikan dan diunggah menggunakan facebook.

\section{SIMPULAN}

Hasil yang didapatkan masih belum begitu menggembirakan di bulan pertama launching produk via facebook meskipun banyak kolega yang sudah melihat, tidak seperti penggunaan instagram yang lebih optimal dan efektif. Hasil tersebut akhirnya menjadikan evaluasi bagi tim pengabdian sehingga metode pemasaran dan sosialisasi/pengenalan produk kopi ini menggunakan media Instagram karena hasilnya lebih efektif jika dibandingkan dengan media facebook. Akhirnya, rebranding yang digunakan dalam kegiatan pengabdian ini adalah dengan membuat akun Instagram yaitu @ diseduh coffe yang dikelola secara profesional oleh anggota Kelompok Tani Harapan, Desa Amadanom, Kecamatan Dampit, Kabupaten Malang.

\section{UCAPAN TERIMA KASIH}

Tim pengabdian berterima kasih kepada seluruh anggota dan pengelola Kelompok Tani Harapan Desa Amadanom Kecamatan Dampit Kabupaten Malang yang telah menerima kami dengan sangat baik dan bersedia bekerjasama dan berkolaborasi sehingga program rebranding ini bisa berjalan sesuai dengan harapan. Tim pengabdian juga berterima kasih kepada Universitas Muhammadiyah Malang yang memberikan dukungan penuh sehingga program pengabdian dengan judul "Pendampingan Rebranding Produk Kopi Kelompok Tani Harapan Desa Amadanom” bisa berlaksana dengan baik.

\section{DAFTAR PUSTAKA}

Dr. Yusman Syaukat, D. L. (2015). Analisis Tematik ST2013 Subsektor ; Dayasaing dan Pemetaan Peremajaan Komoditi Perkebunan. Jakarta: CV. Nario Sari. 
Indira Rezkisari, 2017, Penikmat Kopi Berkualitas Kian Meningkat di Tanah Air, https://www.republika.co.id/berita/gaya-hidup/kuliner/17/07/11/ospx99-penikmat-kopiberkualitas-kian-meningkat-di-tanah-air

International Coffee Organization, 2019, http://www.ico.org/prices/new-consumption-table.pdf

Pemprov Jawa Timur. (2014). Rencana Strategis Tahun 2014 - 2019. Surabaya.

Rukmana, H.Rahmat, 2014, untung selangit dari agribisnis kopi, Yogyakarta: Lily Publisher.

Zakaria, Akhmad. Dkk, 2017, Strategi Pengembangan Usaha Tani Kopi Arabika (Kasus Pada Petani Kopi Di Desa Suntenjayakecamatan Lembang Kabupaten Bandung Barat, Provinsi Jawa Barat),Jurnal sosioteknologi, vol.16 no.3, Desember 2017 